\title{
Nova ruralitat a Catalunya a les últimes dècades: diversificació, emprenedoria i ocupació
}

\author{
Lourdes Viladomiu \\ Jordi Rosell \\ Universitat Autònoma de Barcelona. Departament d'Economia Aplicada \\ lourdes.viladomiu@uab.es \\ jordi.rosell@uab.cat
}

\section{Resum}

L'objectiu de l'article és caracteritzar alguns vectors de la nova ruralitat i assenyalar com això s'ha concretat en la diversificació, l'emprenedoria i les oportunitats laborals de la Catalunya rural a les últimes tres dècades. Per a la realització de l'article hem utilitzat els resultats de diversos projectes de recerca (Canvi rural a Europa, Ideas, Ruremplo, Emprenedoria rural, Rudona, etc.) que, si bé no s'orientaven directament al tema, sí que contenien elements rellevants per a l'anàlisi.

A la nova ruralitat catalana, el sector agrari i el model de modernització tradicional agrària han perdut protagonisme en benefici d'una economia més diversificada. Aquesta diversificació s'ha basat molt sovint en les explotacions agràries que han incorporat noves activitats en proporcionar llocs de treball per a les dones i facilitar la seva continuïtat. En paral.lel, nous emprenedors rurals han contribuït a un canvi incorporant activitats que han trobat en les noves tecnologies de la informació i la comunicació (TIC) un aliat important. Però, a més a més, en aquestes ultimes dècades les polítiques de reequilibri territorial, les polítiques de desenvolupament rural impulsades des d'Europa i l'estat del benestar han proporcionat llocs de treball que avui són un element fonamental de la nova ruralitat catalana. Paraules clau: ruralitat; ocupació; diversificació de les explotacions

Resumen. Nueva ruralidad en Cataluña en las últimas décadas: diversificación, emprendimiento y empleo

El objetivo del artículo es caracterizar algunos factores de la nueva ruralidad y señalar cómo esto se ha concretado en la diversificación, el emprendimiento y las oportunidades laborales. Para la realización del artículo hemos utilizado los resultados de varios proyectos de investigación (Cambio rural en Europa, Ideas, Ruremplo, Emprenedoria rural, Rudona, etc.) que, si bien no se orientaban directamente el tema, sí contenían elementos relevantes para el análisis. 
En la nueva ruralidad catalana, el sector agrario y el modelo de modernización tradicional agraria han perdido protagonismo en beneficio de una economía más diversificada. Esta diversificación se ha basado muy a menudo en las propias explotaciones agrarias que han incorporado nuevas actividades al proporcionar empleos para las mujeres y facilitar su continuidad. En paralelo, nuevos emprendedores rurales han contribuido a un cambio importante de actividades que han encontrado en las nuevas tecnologías de la información y la comunicación (TIC) un aliado fundamental. Asimismo, en las últimas décadas las políticas de reequilibrio territorial, las políticas de desarrollo rural impulsadas desde Europa y el estado del bienestar han proporcionado empleos que son hoy un elemento fundamental de la nueva ruralidad catalana.

Palabras clave: ruralidad; empleo; diversificación de las explotaciones

Résumé. Nouvelle ruralité en Catalogne dans les dernières décennies: diversification, entreprenariat et emploi

Le but de cet article est de caractériser certains facteurs de la nouvelle ruralité en Catalogne et de montrer leur impact sur la diversification, l'entreprenariat et l'emploi. Pour réaliser l'article, nous avons utilisé les résultats de plusieurs projets de recherche (Changement rural en Europe, IDEAS, Ruremplo, Entreprenariat dans les zones rurales, RUDONA, etc.). Ces projets n'étaient pas spécifiquement orientés vers le sujet de l'article mais ils contenaient des éléments pertinents pour l'analyse.

Dans la nouvelle ruralité catalane, le secteur agricole et le modèle traditionnel de la modernisation agricole ont perdu de l'importance face à une économie plus diversifiée. Cette diversification est très souvent basée sur les exploitations agricoles elles-mêmes, qui ont intégré de nouvelles activités en créant des emplois pour les femmes et en facilitant leur continuité. En parallèle, les nouveaux entrepreneurs ruraux ont contribué à une modification importante des activités grâce aux nouvelles technologies de la communication. En outre, au cours des dernières décennies, les politiques de rééquilibrage territorial, les politiques de développent rural d'Europe et l'Etat-providence ont fourni des emplois qui sont maintenant un élément fondamental de la nouvelle ruralité catalane.

Mots-clés: ruralité; emploi; diversification des exploitations agricoles

Abstract. New Catalan rurality in recent decades: diversification, entrepreneurship and employment

The aim of this article is to characterize some elements of the new rurality and to analyse their impact on diversification, entrepreneurship and job opportunities. For this article we used the results of several research projects (Rural Change in Europe, IDEAS, Ruremplo, Entrepreneurship, RUDONA, etc.) which, although not directly oriented to the issue, contained elements relevant to the analysis.

In the new Catalan rurality, agriculture and the traditional model of agricultural modernisation have lost prominence in favour of a more diversified economy. This diversification is very often based on the farms that have incorporated new activities providing jobs for women and facilitating their continuity. In parallel, new rural entrepreneurs have contributed to a significant change in activities thanks to new communication technologies. Also, in recent decades territorial rebalancing policies, European rural development policies and the welfare State have provided jobs that are now a fundamental element of the new Catalan rurality.

Keywords: rurality; employment; diversification of farms 


\section{Sumari}

\section{Introducció}

2. La diversificació de les explotacions agràries

3. Accés als serveis, desenclavament geogràfic, TIC i qualitat de vida
4. L'emprenedoria i
el desenvolupament endogen
5. Les dones i el món rural
6. Conclusions
Referències bibliogràfiques

\section{Introducció}

Als anys vuitanta, els estudiosos de les ciències socials als països més desenvolupats van revisar profundament la visió del món rural. Aquesta revisió va ser conseqüència indubtablement de molts factors, però dos hi van influir de forma molt significativa. D'una banda, la Comissió Europea requeria un nou plantejament per a la Política Agrícola Comuna (PAC) i la seva necessària reforma; d'altra banda, la crisi dels anys setanta havia comportat una important redefinició dels espais geogràfics i les seves dinàmiques poblacionals en haver minvat les sortides generalitzades de població del món rural amb destinació urbana.

El document «El futuro del mundo rural» (Comissió Europea, 1988) va manifestar que hi havia diferents espais rurals: les zones periurbanes, les zones rurals profundes i les zones intermèdies, però també va constatar que en tots aquests entorns l'agricultura anava perdent posicions i que l'economia d'aquestes àrees s'anava transformant. El projecte europeu «Canvi rural a Europa: Programa d'investigació sobre les estructures d'explotació i pluriactivitat", realitzat entre 1986 i 1992 per un amplíssim equip d'investigadors sota la direcció de l'Arkleton Trust ${ }^{1}$, va posar en evidencia l'important desenvolupament de la pluriactivitat de les famílies agràries europees i va manifestar que l'economia rural era molt més que l'activitat agrària fins i tot analitzant les economies dels agricultors (Arkleton Trust, 1992; Etxezarreta et al., 1995). Rural i agrari havien estat considerats durant molt de temps sinònims i això comportava una visió molt estreta de les opcions de les zones rurals. En aquells anys, les polítiques agràries tradicionals es veien seriosament afectades pels desequilibris en els mercats $i$, per tant, era necessària una reconsideració dels seus objectius i instruments. El resultat de tots els canvis que ha anat experimentant la societat rural des de mitjan anys vuitanta s'ha ubicat dins el paraigua del que s'anomena la «nova ruralitat».

L'objectiu de l'article és caracteritzar alguns vectors de la nova ruralitat i assenyalar com això s'ha concretat en oportunitats laborals, és a dir, descriure

1. L'Arkleton Trust va ser fundat a Escòcia el 1977 per estudiar nous enfocaments per al desenvolupament rural i l'educació. Des de 1985 va ser una institució molt activa a l'àmbit de la recerca sobre desenvolupament rural. Al 1995 es va transformar en el Arkleton Institute for Rural Development Research a la Aberdeen University 
les opcions laborals que la nova ruralitat comporta i analitzar-ne les oportunitats i els reptes. Per a la realització de l'article utilitzarem els resultats de diferents projectes de recerca en què hem participat en aquests últims anys i que, si bé no s'orientaven directament al tema, sí que contenien elements rellevants per a la tasca que ens ocupa. Amb tot, som conscients que es tracta d'una anàlisi que aporta pinzellades i que s'hauria de completar amb un estudi específic sobre ocupació i nova ruralitat tant quantitatiu com qualitatiu.

A la primera part analitzarem la diversificació de les explotacions agràries; la segona part, la dedicarem als canvis en la qualitat de vida de les zones rurals gràcies a les noves tecnologies de la informació i la comunicació (TIC), a les infraestructures de transports i als serveis públics i privats; a la tercera part farem referència a l'emprenedoria com a element del dinamisme rural de les ultimes dècades; la quarta part és dedicada a les dones en el món rural i l'ocupació; i finalitzarem l'article amb unes conclusions.

\section{La diversificació de les explotacions agràries}

L'especialització productiva de les explotacions agràries i també dels territoris rurals és un dels trets del procés de canvis experimentats pel món rural al llarg del segle xx. Les explotacions agràries s'han anat convertint en unitats productives especialitzades en un o pocs productes i sovint en una part petita de la cadena productiva del producte. Aquest procés, de fet, no és més que l'aplicació al sector primari d'una tendència general de l'economia resultat de la creixent rellevància dels intercanvis (Garrabou, 2006).

El prototip de la modernització agrària que es va imposar a Espanya des dels anys seixanta conduïa a grans explotacions fortament especialitzades en uns pocs productes agrícoles o ramaders $\mathrm{i} \mathrm{amb}$ mà d'obra a dedicació exclusiva (Magrama, 2003; Etxezarreta et al., 2015). Aquest model va fer desaparèixer moltes de les activitats complementàries que havien estat pròpies de tota masia catalana i que servien per garantir una forta autosuficiència i ocupaven preferentment treball femení.

L'especialització es va considerar l'únic camí a la rendibilitat i viabilitat de les explotacions agràries. La realitat va evidenciar que no era tan hegemònic com havien previst els estudiosos. Malgrat aquesta tendència general cap a l'especialització de les explotacions, també n'hi ha d'altres que opten per una via oposada: la diversificació d'activitats (Arkleton Trust, 1992; Bryden i Fuller, 1994, Etxezarreta et al., 1995). El projecte de recerca Innovation, diversification and European agricultural situations - Ideas (EU Project FAIR 6-CT98-4228), realitzat en el període 1999-2001, tenia per objectiu identificar exemples dinàmics de la diversificació innovadora a l'explotació agrària en quatre regions de la UE (Västerbotten a Suècia, Llenguadoc-Rosselló a França, Catalunya a Espanya, i Lincolnshire al Regne Unit), amb èmfasi en la creació d'oportunitats d'ocupació ${ }^{2}$.

2. Més informació sobre aquesta recerca a: <http://cordis.europa.eu/project/rcn/48231_en.html>. 
El projecte va evidenciar la gran varietat d'aquestes activitats de diversificació que s'havien anant desenvolupat dins les explotacions agràries catalanes i a altres zones d'Europa. De fet, les explotacions agràries catalanes sovint eren veritables empreses rurals diversificades (Viladomiu et al., 2002).

No hi ha una definició única i plenament acceptada de diversificació de les explotacions agràries. $\mathrm{Al}$ nostre parer, per aproximar-se a la diversificació de les explotacions cal considerar les activitats que tenen el suport dels actius materials i humans de l'explotació i que, per tant, es realitzen dins de la mateixa explotació. En segon lloc, cal incloure tant la diversificació basada en l'agricultura pròpiament dita com la no agrària. En tercer lloc, cal considerar molt especialment com a diversificació les activitats agràries que inclouen un component de novetat, singularitat o innovació, que són les més dinàmiques i que ens informen dels canvis i les vetes de mercat que s'aprofiten en cada període.

La ruralitat catalana, al final de la dècada dels noranta, estava constituïda per un teixit d'empreses, fonamentalment familiars, en què els ingressos provenien de diferent fonts. No tenim, però, estadístiques precises per mesurar la rellevància de les activitats de diversificació en el conjunt d'ingressos de les explotacions agràries catalanes. Només disposem d'una aproximació a l'abast de les activitats de diversificació a les explotacions agràries per mitjà dels censos agraris i les enquestes sobre l'estructura de les explotacions agràries, on es pregunta sobre les «activitats complementàries» de les explotacions. La taula 1 dóna compte de les dades més recents.

Un comentari especial mereix el cas del turisme, una activitat fonamental dins la diversificació del món rural català. Catalunya és una potència turística de primer nivell, i, si bé al principi es va produir una especial concentració del turisme a les zones costaneres, seguint el model de sol i platja, posteriorment el turisme s'ha anat dispersant a nous àmbits, incloent-hi les zones rurals, fet

Taula 1. Explotacions amb altres activitats complementàries en què s'utilitzen els recursos o els productes de l'explotació

\begin{tabular}{lrrr}
\hline \multicolumn{1}{c}{ Activitat } & 1999 & 2009 & 2013 \\
\hline Turisme, allotjament i altres activitats recreatives & 438 & 679 & 931 \\
Artesania & 77 & 31 & 3 \\
Transformació de productes agraris & 700 & 446 & 327 \\
Producció d'energia renovable & 83 & 94 & 37 \\
Transformació de fusta & 102 & 27 & 182 \\
Treballs agrícoles sota contracte per a altres explotacions & n.d. & 567 & 908 \\
Treballs no agrícoles sota contracte & n.d & 147 & 95 \\
Silvicultura & n.d & 184 & 385 \\
Venda directa & 5368 & n.d. & n.d \\
Altres & 488 & 388 & 576 \\
\hline
\end{tabular}

Font: Idescat, a partir de les dades del Cens agrari de I'INE i de l'Enquesta sobre l'estructura de les explotacions agràries de l'INE. 
Taula 2. Classificació de les activitats de diversificació a l'explotació agrària segons resultats del projecte Ideas

1. Diversificació de la producció agrària

Cultius i ramaderia no convencional

Activitat forestal no convencional

Aqüicultura

Apicultura

\section{Diversificació tradicional}

Transformació de productes agraris

Venda directa de productes agraris i d'elaboració pròpia

Contractació i lloguer de maquinària agrícola

Serveis agraris

\section{Producció i serveis no agraris}

Allotjament i restauració

Activitats d'oci/recreatives

Lloguer de terres i edificis per a usos no agraris

Venda de productes no agraris

Artesania

Energies renovables

Serveis professionals

\section{Pràctiques agroambientals}

Agricultura biològica

Producció integrada

Pràctiques agroambientals

Font: elaboració pròpia.

que ha donat lloc a un increment dels allotjaments i altres serveis turístics a les explotacions agràries (Francés, 2007).

La taula 2 presenta una llista d'activitats que en la recerca Ideas vam trobar dins la mostra d'explotacions.

A la recerca esmentada es va analitzar una mostra de 85 explotacions catalanes diversificades i de 40 de no diversificades. D'aquestes 85 explotacions, 56 tenien una sola activitat complementària o diversificada, 23 en tenien dues i 6 en tenien 3. En total, 120 activitats de diversificació, la qual cosa correspon a una mitjana d'1,41 activitats diversificades per explotació. En aquesta mostra, la diversificació en productes i serveis no agraris i la diversificació tradicional eren majoritàries (taula 3).

La caracterització de les explotacions diversificades de la nostra mostra ens dóna compte d'un perfil de titular d'explotacions diversificades: més jove, millor format $\mathrm{i}$ amb més experiència laboral prèvia fora del sector agrari que els titulars de la mostra d'explotacions no diversificades. La diversificació també reflecteix una major participació de les dones en relació amb les explotacions no diversificades.

Aquell estudi també ens va permetre afirmar que la diversificació feia una contribució substancial a la viabilitat econòmica de les explotacions. Les acti- 
Taula 3. Tipus de diversificació prioritària segons resultats del projecte Ideas

\begin{tabular}{lcc}
\hline & Nre. & Percentatge \\
\hline Productes agraris no convencionals & 12 & $10 \%$ \\
Diversificació tradicional & 43 & $35 \%$ \\
Productes i serveis no agraris & 43 & $35 \%$ \\
Pràctiques agroambientals & 27 & $20 \%$ \\
Total & 125 & $100 \%$ \\
\hline
\end{tabular}

Font: Viladomiu et al. (2002).

vitats de diversificació aporten una mitjana del $44 \%$ dels ingressos totals de les explotacions diversificades, fet que evidencia la rellevància d'aquestes activitats. S'ha de destacar, també, que les explotacions diversificades depenen només en un $10 \%$ dels seus ingressos de les subvencions agràries, mentre que per a les explotacions no diversificades aquesta dependència és, segons els resultats de les enquestes, lleugerament superior (16\%). La rellevància de l'aportació d'ingressos de les activitats diversificades resulta coherent amb el fet que la generació d'ingressos és la raó més citada (73\% dels casos) per justificar la diversificació. També que el $86 \%$ de la mostra considera l'augment d'ingressos com un dels beneficis de la diversificació. La diversificació també és vista per un $40 \%$ dels entrevistats com una via per generar oportunitats laborals als membres de la família, la qual cosa afavoreix una major participació laboral de les dones. En el cas del turisme es valoren, així mateix, els contactes socials que possibilita.

La diversificació de les explotacions agràries és un element clau per mantenir i crear llocs de treball dins les famílies agràries, que l'especialització hauria destruït. És també una via per assegurar la viabilitat econòmica d'unes explotacions que, per la seva dimensió o situació geogràfica, no eren viables en el model estàndard d'especialització. La diversificació és part d'aquesta nova ruralitat que cerca noves opcions.

\section{Accés als serveis, desenclavament geogràfic, TIC i qualitat de vida}

El projecte Agriculture and employment in the rural regions of the EU - (Ruremplo) (EU Project No FAIR 3-CT96-7666), que es va desenvolupar de 1997 a 1998, tenia com a objectiu l'anàlisi de l'evolució de l'ocupació a les regions rurals de la UE, així com dels factors que permetien diferenciar zones rurals amb èxit de zones rurals fracassades ${ }^{3}$. L'indicador que permetia diferenciar ambdós tipus de zones era el comportament recent de l'ocupació. A grans trets, les raons de l'èxit d'algunes zones rurals europees en relació amb d'altres es basava fonamentalment en un conjunt de factors que es poden sintetitzar

3. Més informació sobre aquesta recerca a: <http://cordis.europa.eu/project/rcn/37427_ en.html>. 
en: diversificació de la producció agrària i potenciació de la transformació de productes agraris; manteniment i diversificació de la indústria tradicional; disponibilitat d'infraestructures que havien permès mitigar l'aillament geogràfic; la dotació de serveis bàsics a la població i l'accessibilitat a aquests, i una qualitat de vida que permetia els beneficis de la natura sense renunciar a la socialització (Terluin i Post, 2000; Rosell et al., 2000).

El desenclavament de les zones rurals s'ha vist, a més a més, molt afavorit pel desenvolupament de les noves tecnologies de la informació i la comunicació. Aquestes han estat un element fonamental que permet la deslocalització de llocs de treball, amb la possibilitat que professionals de diferents sectors realitzin la seva activitat fora dels seus despatxos urbans. Però també les TIC han permès la implantació d'empreses en entorns de baixa densitat, on han sorgit noves empreses de sectors molt diferents (Viladomiu et al., 2004). Per acabar, cal assenyalar que les TIC han apropat els modes de vida urbans i rurals i han trencat l'aillament personal que sentien molts dels habitants rurals (Bryden i Fuller, 1987).

La disponibilitat més gran de serveis i d'infraestructures en el medi urbà ha estat afavorida en el cas català per una política deliberada de reequilibri territorial a tots els nivells administratius. Les administracions públiques catalanes han dut a terme una política territorial que ha contribuït a millorar la disponibilitat de serveis i infraestructures al medi rural. La Unió Europea hi ha tingut un protagonisme important amb els recursos provinents del diferents fons estructurals, entre els quals hem de citar els corresponents a l'antiga secció d'estructures del Fons Europeu d'Orientació i Garantia Agrària (FEOGA) i el Fons Europeu Agrari i de Desenvolupament Rural (FEADER) per mitjà dels Programes de Desenvolupament Rurals (PDR), i amb altres iniciatives que han afavorit la localització d'activitats i serveis en zones rurals (Rosell i Viladomiu, 2009). Però també tots els altres nivells administratius han treballat des de la fi del franquisme per un apropament dels estàndards de vida en el conjunt del territori. Els nous serveis i les intervencions públiques pròpies de l'estat del benestar han estat un element fonamental en la generació de noves ocupacions que han impactat molt favorablement en la dinàmica de la població en aquests territoris i han generat les condicions per fer viable la diversificació de les explotacions (Rosell et al., 2007).

La nova ruralitat ha trobat en les noves tecnologies un aliat fonamental, però també les polítiques de reequilibri territorial i el desenvolupament de l'estat del benestar han estat clau per canviar la societat rural i generar en el territori rural llocs de treball apropiats per a una mà d'obra assalariada i qualificada.

\section{L'emprenedoria i el desenvolupament endogen}

Els anys vuitanta també van suposar un canvi en les polítiques de desenvolupament local, ja que les estratègies exògenes seran substituïdes per plantejaments endògens. Des de l'òptica exògena, un territori poc desenvolupat es caracteritzava per la manca dels factors clau per al creixement. No hi ha capital 
per invertir, no hi ha treball qualificat, no hi ha esperit emprenedor, no hi ha infraestructures, i així una llarga llista. És a dir, la política per ajudar aquests territoris ha de consistir, segons aquest plantejament, a transferir des de fora de la zona els factors en forma d'empreses, capital i tècnics. Es tracta d'una intervenció exògena seguint unes pautes homogènies per a totes les zones. Aquesta estratègia va ser molt costosa i va tenir uns resultats molt pobres, ja que es van construir veritables «catedrals al desert» que no generaven l'efecte d'arrossegament ni ocupació per a la població rural. Amb la crisi dels anys setanta hi va haver un canvi d'orientació $\mathrm{i}$ les estratègies endògenes van passar a ser les protagonistes principals de les actuacions públiques en l'àmbit local i, més específicament, en l’àmbit rural (Santacana et al., 1987).

Tanmateix, el reconeixement de la necessitat de diversificar l'economia rural i el predicament del desenvolupament endogen no van donar lloc a una atenció immediata a la problemàtica relacionada amb l'empresariat. Durant anys, la creació, el desenvolupament i la modernització d'empreses no va rebre una atenció prioritària. L'èmfasi es va posar en altres qüestions, com els recursos materials de què disposaven les zones rurals, l'existència d'una demanda per sostenir les activitats de diversificació o la capacitat d'atracció cap al món rural d'algunes activitats localitzades en entorns urbans. En aquest últim cas, es destacaven els avantatges que oferien les zones rurals per al desenvolupament d'algunes activitats productives. L'existència de zones rurals amb activitat manufacturera —els districtes industrials rurals — també va ser objecte d'anàlisi. Però els treballs sobre els districtes industrials es van interessar més per les relacions interempresarials i els trets característics de les relacions laborals que no pas per les qüestions relacionades directament amb l'empresariat (Trullén, 1990; Boix i Galleto, 2006).

La situació va anar canviant des del començament d'aquest segle; en efecte, tant a Europa com als Estats Units, sembla que s'està pal.liant aquesta manca d'interès per la problemàtica empresarial en el món rural. D'una banda, per la creixent atenció que aquesta temàtica ha adquirit en el món acadèmic i polític i la seva relació amb el desenvolupament local (OECD, 2003). D’una altra, el risc que la globalització limiti la incidència de les polítiques tradicionals de localització d'empreses en zones rurals basades a atorgar incentius econòmics i aprofitar l'existència de baixos costos (Drabnesntott et al., 2003; Kellogg Foundation, 2003) ha comportat una major atenció cap a estratègies de creació i consolidació de l'emprenedoria en el món rural.

Finalment, els nous plantejaments del desenvolupament rural — basats en un enfocament participatiu, territorial i de baix a dalt- són una oportunitat per donar suport al naixement i la consolidació d'empreses en el món rural. El programa de foment del desenvolupament endogen per excelllència en el món rural ha estat la iniciativa comunitària Leader, que es va iniciar el 1991 en el marc de la política de desenvolupament rural de la Unió Europea (Observatori Europeu Leader - AEIDL, 1999). Mitjançant aquesta iniciativa, les zones rurals emmarcades en territoris relativament homogenis i amb poblacions properes als 20.000 habitants defineixen els seus plans de desenvolupament 
a partir de mobilitzar els seus recursos propis i definir la millor estratègia per potenciar el seu desenvolupament. D'acord amb l'estratègia, s'aproven i se subvencionen projectes que afavoreixin l'emprenedoria de les poblacions rurals donant suport principalment a pimes, empreses turístiques i de tot tipus de serveis per a la població.

En el cas de Catalunya, un criteri que van recollir els programes Leader va ser la generació d'ocupació. Els resultats es van avaluar donant molta importància als indicadors de llocs de treball creats o consolidats i prioritzant les dones i els joves. Pel que fa al Programa Leader II de Catalunya, executat entre 1995 i 1999 , els projectes que van rebre el seu suport van crear més de 1.500 llocs de treball a una mitjana de 2,1 nous ocupats per projecte i amb una inversió mitjana de quasi 60.000 euros per lloc de treball. Els projectes de l'àmbit de les petites empreses, artesania i serveis de proximitat van ser els que van mostrar major capacitat de generar ocupació, amb una mitjana de 3,9 llocs de treball per projecte i una inversió mitjana de 36.000 euros per lloc de treball. En l'àmbit del turisme rural es van generar 1,4 llocs de treball per projecte. Cal destacar també que els llocs de treball creats van ser ocupats quasi a parts iguals entre homes i dones. Específicament, en les activitats de turisme rural es van generar més llocs de treball femenins que masculins (Rosell et al., 2001).

D'altra banda, diferents estudis realitzats durant aquells anys (Vaillant $\mathrm{i}$ Lafuente, 2012; Viladomiu et al., 2004, Mancilla et al., 2010) van manifestar un grau d'emprenedoria molt elevat als municipis rurals de Catalunya. L'estudi de la Fundació Empresa i Ciència ${ }^{4}$ sobre «Empresaris i empreses en el món rural català», realitzat el 2002-2003, tenia per objectiu analitzar els trets distintius de l'empresariat de les zones rurals catalanes així com també identificar els reptes per desenvolupar la seva activitat en aquests territoris. En l'estudi vam apreciar que emprendre era principalment el resultat de detectar possibilitats de negoci mobilitzant recursos disponibles i aprofitant el suport de les actuacions públiques, mentre que la manca de llocs de treballs tenia una importància marginal en les decisions d'emprendre (Viladomiu et al., 2004).

\section{Les dones i el món rural}

L'emergència del model «productivista» agrícola, amb l'especialització, la mecanització i l'augment de la dimensió de les explotacions agràries, va limitar fortament les opcions laborals de les dones a les zones rurals. Si a més a més tenim en consideració que el diferencial en les condicions de vida es va ampliar a passos de gegant durant els anys seixanta i setanta, i que la figura de l'agricultor era poc valorada socialment, el resultat és que les dones joves van ser les principals protagonistes d'una emigració rural de grans dimensions (Camarero, 1991).

4. La Fundació Empresa i Ciència va ser constituïda per la Universitat Autònoma de Barcelona i la Cambra Oficial de Comerç, Indústria i Navegació de Barcelona, l’any 1983, per impulsar les relacions entre la Universitat i l'empresa. 
L'esmentat projecte «El canvi rural a Europa», realitzat en el període 19861992, tenia com a objectiu l'estudi de la pluriactivitat dins de la dinàmica de l'explotació agrària ${ }^{5}$. Un dels resultats de l'estudi va ser saber que el manteniment de les explotacions agràries en zones rurals profundes depenia molt sovint més de la capacitat que tenien els agricultors de casar-se i formar família que no pas de la rendibilitat de l'explotació (Arkleton Trust, 1992; Etxezarreta et al., 1995). La manca de llocs de treball i d'oportunitats per a les dones al món rural va contribuir al seu èxode. La crisi social que va generar el desequilibri de gènere, amb una taxa de masculinitat en edats compreses entre els trenta i els seixanta-cinc anys molt elevada, va fer preveure un dolorós final per a bona part de les zones rurals i la seva entrada en una situació de marginalització (Pinto Correira i Breman, 2008; Rosell et al., 2008).

En aquest context, la dona va adquirir un protagonisme fonamental en la nova ruralitat i això s'ha plasmat en l'estreta relació entre la diversificació productiva al medi rural, l'accés de les dones al mercat de treball i les iniciatives emprenedores. Quan ens hem ocupat de la diversificació a les explotacions agràries hem descobert el protagonisme de les dones, especialment en activitats com la venda directa, la transformació de productes agraris i els allotjaments rurals (Viladomiu et al., 2002). De fet, dins i fora de les explotacions agràries, la dona ha estat clau en el desenvolupament del turisme rural (Francés, 2007).

A les iniciatives d'emprenedoria al món rural hem detectat un paper rellevant de les dones. Al Programa Leader+ de Catalunya (1994-1999) les dones van ser les promotores de la meitat del projectes individuals. Les dones promotores de projectes del Programa Leader+ eren joves, majoritàriament amb formació mitjana o universitària i amb formació notablement superior a la dels homes promotors. A més, la participació de les dones era més gran en la promoció de noves activitats i més reduïda en els projectes d'ampliacions d'empreses ja existents (Viladomiu et al., 2010b).

Al Programa Leader+, la major presència de dones emprenedores la trobàvem en l'àmbit del turisme rural, però tenien particular rellevància les iniciatives en altres activitats de serveis a la població així com en la comercialització i transformació de productes agraris.

L'estudi de la Fundació del Món Rural sobre noves oportunitats d'ocupació per a les dones al món rural català (Rudona), que es va desenvolupar el 2009, tenia com a objectius detectar les oportunitats d'ocupació per a les dones rurals motivades pel desenvolupament dels nous jaciments d'ocupació en zones rurals, analitzar les possibilitats de la política de desenvolupament rural en l'enfortiment d'aquests jaciments i valorar la incidència del desenvolupament dels nous jaciments d'ocupació en la cobertura de les necessitats socials ${ }^{6}$. A l'estudi vam identificar com a jaciments amb major protagonisme femení els serveis per a gent gran, infants i joves amb dificultats d'inserció; el turisme; les activitats esportives;

5. Més informació sobre el projecte a Arkleton Research (1990).

6. Més informació sobre el projecte a: <http://www.rudona.cat/>. 
l'elaboració i comercialització de productes alimentaris de qualitat; i, en menor mesura, els transports col-lectius (Viladomiu et al., 2009). En els serveis públics, la dona ha ocupat molts dels llocs de treball que s'han generat als ajuntaments, als consell comarcals, a les biblioteques públiques, als hospitals i a les escoles. La generació de llocs de treball ocupats per dones des del sector públic en el marc de l'estat del benestar ha estat molt important $\mathrm{i}$ ha contribuït a una millora del nivell de vida de les zones rurals (Viladomiu et al., 2009; Viladomiu et al., 2010a).

\section{Conclusions}

El canvis que han donat lloc a la nova ruralitat han generat un degoteig de noves ocupacions en el món rural que han estat afavorides per una disponibilitat més gran d'infraestructures i de serveis i per la possibilitat de deslocalitzar alguns llocs de treball de les grans urbs metropolitanes gràcies a les noves tecnologies de la informació i la comunicació (TIC). També es tracta sovint d'ocupacions creades per les administracions locals i per l'estat del benestar amb l'objectiu d'afavorir l'equilibri territorial, d'ocupacions en serveis fortament elàstics amb el nivell de renda gràcies al creixement econòmic espanyol, d'ocupacions resultat de l'avenç del turisme rural i també d'ocupacions conseqüència del dinamisme constructor, de moltes petites indústries lligades a la construcció i dels serveis immobiliaris.

Aquestes noves ocupacions han incidit molt favorablement en la incorporació de les dones en el món laboral rural, la qual cosa ha permès una dinamització demogràfica. Dinamització també gràcies a l'arribada de molta població, especialment immigrants de fora d'Espanya. Els habitants de molts pobles de Catalunya presenten elevats percentatges d'estrangers.

A més a més, la generació d'ocupació ha tingut el suport molt sovint de l'emprenedoria local, que fa que els agents locals hagin tingut un gran protagonisme en el procés. Les famílies d'agricultors han diversificat les fonts d'ingressos gràcies a noves empreses. Aquestes noves activitats són viables gràcies a una forta complementarietat entre elles i permeten aprofitar les economies d'abast o de diversificació. Sovint les explotacions agràries catalanes són centres d'empreses amb moltes activitats que es complementen i que en permeten la viabilitat econòmica.

La nova ruralitat s'ha anat generant amb una forta implicació del sector públic i de les polítiques actives de desenvolupament de les zones rurals. La reforma dels fons estructurals de 1988 va forçar, a causa del règim de cofinançament, a fer que totes les administracions nacionals i regionals donessin una major envergadura a l'equilibri territorial i posessin més recursos financers a les zones rurals. Les reformes de la PAC van transferir més recursos al segon pilar - desenvolupament rural - en potenciar els programes de desenvolupament rural (PDR) amb recursos de diferents orígens públics.

Els anys de la crisi (2008-2015) han servit per manifestar que moltes de les infraestructures i serveis nascuts en els anys del boom no han suportat 
l'austeritat. Alguns serveis van ser dissenyats amb uns cànons propis del món urbà i no van aconseguir una afluència de públic suficient per garantir la sostenibilitat. Molts negocis privats tampoc no han resistit la caiguda de la capacitat adquisitiva ni la creixent competència en els mercats. El fre de l'activitat constructora i immobiliària ha destruït molts llocs de treball i ha fet recular els habitants d'algunes zones. Els anys de la crisi han enfonsat molts projectes empresarials.

En conseqüència, les zones rurals s'han enfrontat a grans dilemes en aquests últims anys, que no han tingut una resposta facil. Però, fins i tot en aquest context desfavorable, es pot apreciar la consolidació d'una «nova ruralitat» que ha comportat un canvi en la imatge social de l'agricultor, del camp i de la vida en el món rural. Els mitjans de comunicació projecten avui una imatge molt diferent de la de fa trenta anys. En el futur proper veurem si la nova ruralitat és un fet sòlid o és conseqüència d'una economia fortament assistida que va generar un miratge.

\section{Referències bibliogràfiques}

Arkleton Reasearch (1990). Cambio rural en Europa: programa de investigación sobre las estructuras agrarias y la pluriactividad. Madrid: Ministerio de Agricultura, Pesca y Alimentación.

ArkLeton Trust (1991). Proceedings of the Braemar Colloquium: Rural change in Europe. Berkshire: Arkleton.

Boix, R. i Galletto, V. (2006). «Sistemas industriales de trabajo y distritos industriales marshallianos en España». Economía Industrial, 359, 165-184.

Bryden, J. i Fuller, A. (1986). New technology and rural development. Berkshire: Arkleton.

Camarero, L. A. (1991). «Tendencias recientes y evolución de la población rural en España». Politica y Sociedad, 8, 13-24.

Comisión Europea (1988). El futuro del mundo rural. Comunicación de la Comisión al Parlamento Europeo y al Consejo [COM(88) 501 final]. Luxemburg: Oficina de Publicaciones Oficiales de las Comunidades Europeas.

Drabenstott, M.; Novack, N. i Abraham, B. (2003). «Main Streets of Tomorrow: Growing and Financing Rural Entrepreneurs. A Conference Summary». The Main Street Economist. Center for the Study of Rural America Kansas City, Missouri.

Etxezarreta, M.; Cruz, J.; García Morilla, M. i Viladomiu, L. (1995). La agricultura familiar, ante las nuevas politicas agrarias comunitarias. Madrid: Ministerio de Agricultura, Pesca y Alimentación.

Etxezarreta, M.; Rosell, J. i Viladomiu, L. (2015). «An overview of Spanish agriculture in the 21st century». A: Bonanno, A. i Busch, L. (eds.). Handbook of the International Political Economy of Agriculture and Food. Cheltenham: Edward Elgar Publishing, 191-209.

FranCÉs, G. (2007). «La incidencia de las redes sociales en el desarrollo del agroturismo». Revista Española de Estudios Agrosociales y Pesqueros, 213, 103-124

Garrabou, R. (2006). «L'herència històrica: la fi del món pagès i el futur problemàtic de l'agricultura industrialitzada». Garrabou, R. (coord.). Història agrària dels Països Catalans. Vol. Iv. Barcelona: Publicacions i Edicions de la Universitat de Barcelona. 
Kellogg Foundation (2003). Mapping Rural Entrepreneurship. <http://www.wkkf. org/news-and-media/article/2005/10/mapping-rural-entrepreneurship $>$.

MAGRAMA (2003). Libro blanco de la agricultura y el desarrollo rural. Madrid: Ministerio de Agricultura, Pesca y Alimentación.

Mancilla, C.; Viladomiu, L. i Guallarte, C. (2010). «Emprendimiento, inmigrantes y municipios rurales: el caso de España». Economía Agraria y Recursos Naturales, $10(2), 121-142$.

Observatorio Europeo Leader - AEIDL (1999). "La competitividad territorial. Construir una estrategia de desarrollo territorial con base en la experiencia de Leader». Innovación en el medio rural, 6 (1).

OECD (2003). Entrepreneurship and local economic development: Programme and Policy Recommendations. París: OECD Publications Service.

Pinto-Correira, T. i Breman, B. (2008). «Understanding marginalisation and multifunctionality». A: Brouwer, F.; Rheenen, T. van; Dhillion, S. S. i Elgersma, A. M. (eds.). Sustainable Land Management. Strategies to cop with marginalisation of agriculture. Cheltenham: Edward Elgar Publishing, 11-40.

Rosell, J.; Viladomiu, L. i Francés, G. (2000). «Comparison of the Spanish Case Studies: Albacete and Zamora». A: Terluin, I. J. i Post, J. H. (eds.). Employment dynamics in rural Europe. Wallingford: CABI, 115-136.

Rosell, J.; Viladomiu, L.; Etxezarreta, M. i Soldevila, V. (2001). Evaluación de los Programas de Innovación Rural de la Iniciativa Leader II de Cataluña, 19941999. Barcelona: Departament d'Agricultura, Ramaderia i Pesca de la Generalitat de Catalunya.

Rosell, J.; Vaillant, Y. i Viladomiu, L. (2007). «Apoyo a las empresas y empresarios en las zonas rurales de Cataluña». Revista de Estudios Regionales, 77, 29-59.

Rosell, J.; Viladomiu, L. i Zamora, A. (2008). «Marginalistion in Spanish dry areas: The case of Villafáfila Lagoons Reserve». A: Brouwer, F.; Rheenen, T. van; DHILlion, S. S. i Elgersma, A. M. (eds.). Sustainable Land Management. Strategies to cop with marginalisation of agriculture. Cheltenham: Edward Elgar Publishing, 149-170.

Rosell, J. i Viladomiu, L, (2009). «Los Programas de Desarrollo Rural (2007-2013) de la Unión Europea y sus enfoques alternativos». A: Moreno, L.; SánChez, M. i Simôes, O. (eds.). Cultura, innovação e território: o agroalimentar e o rural. Lisboa: Sociedade Portuguesa de Estudos Rurais.

Santacana, F.; Guinjoan, M.; Pellicer, P. i Vázquez Barquero, A. (dirs). (1987). Áreas rurales con capacidad de desarrollo endógeno. Madrid: Ministerio de Fomento - Instituto del Territorio y Urbanismo.

Terluin, I. J. i Post, J. H. (eds.) (2000). Employment dynamics in rural Europe. Wallingford: CABI.

TRullén, J. (1990). "Caracterización de los distritos industriales. El distrito marshaliano en el debate actual sobre desarrollo regional y localización industrial». Economía Industrial, 273, 151-163.

Vaillant, Y. i Lafuente, E. (2012). Informe GEM Catalunya 2011. Global Entrepreneurship Monitor.

Viladomiu, L.; Rosell, J. i Francés, G. (2002). «La diversificación de las explotaciones agrarias catalanas: hechos y realidades». Estudios Agrosociales y Pesqueros, 195, 9-36.

Viladomiu, L.; Rosell, J.; Vaillant, Y. i Zamora, A. (2004). Empresas y empresarios en las comarcas rurales de Catalunya. Bellaterra: Centre d'Economia Industrial Fundació Empresa i Ciència. 
Viladomiu, L.; Rosell, J.; Correa, M. i Francés, G. (2009). Diagnosi sobre noves oportunitats d'ocupació per a les dones al món rural català. Projecte Rudona. Lleida: Fundació del Món Rural.

Viladomiu, L.; Rosell, J. i Forcada, O. (2010a). Estudi de detecció de nous jaciments d'ocupació a les comarques rurals catalanes. Projecte Rural Activa. Lleida: Fundació del Món Rural.

Viladomiu, L.; Rosell, J. i Francés, G. (2010b). «Factores determinantes de la participación de la mujer como promotora de proyectos Leader+». Revista Española de Estudios Agrosociales y Pesqueros, 226, 177-206. 